TEME, г. XLIII, бр. 2, април - јун 2019, стр. 355-374

Прегледни рад $\quad$ https://doi.org/10.22190/TEME171011023S

Примљено: 11. 10. 2017.

UDK 004.738.5:81’243

Ревидирана верзија: 27. 08. 2018.

Одобрено за штампу: 5. 10. 2018.

\title{
RELATIONSHIP BETWEEN SOCIAL NETWORKS AND DIGITAL MEDIA ENGAGEMENT AND STUDENTS' MOTIVATION TO LEARN ENGLISH
}

\author{
Jelisaveta Šafranj", Jelena Zivlak, Ranko Bojanić \\ University of Novi Sad, Faculty of Technical Sciences \\ *jsafranj@eunet.rs
}

\begin{abstract}
The paper deals with the relationship between social networks and digital media engagement and students' motivation to learn English. The research included 353 engineering students at XXX, who answered the questionnaire which was divided into two parts considering social networks and digital media engagement, and motivation to learn English. An exploratory factor analysis has yielded three distinct factors of social networks and digital media engagement and one factor of motivation to learn English. The research provided empirical confirmation of the existence of the mentioned factors. This four-factor solution was found to be statistically reliable, and it has been shown that factors are positively associated. Moreover, the research findings proved that students' motivation to learn English is more fostered with the need to read, learn and chat than to craft, produce and develop digital and social media content. Students have integral motivation for learning English through social networks and digital media.
\end{abstract}

Key words: $\quad$ social networks, English language, integral motivation, digital media, engineering students.

\section{ОДНОС ИЗМЕБУ ДРУШТВЕНИХ МРЕЖА \\ И ДИГИТАЛНИХ МЕДИЈА И МОТИВАЦИЈЕ СТУДЕНАТА ЗА УЧЕЊЕ ЕНГЛЕСКОГ ЈЕЗИКА}

\footnotetext{
Апстракт

У раду се говори о односу између друштвених мрежа и дигиталних медија и мотивације студената за учење енглеског као страног језика. Истраживањем је обухваћено 353 студента техничких наука који су одговорили на упитник који је састављен из два дела. Први део односи се на укљученост студената у дигиталне медије, а други на њихову мотивацију за учење енглеског језика. Експлоративна факторска анализа издвојила је три фактора укључености у друштвене мреже и дигиталне медије, те један фактор мотивације за учење енглеског језика. Истраживање је омогућило емпиријску потврду постојања наведених фактора. Утврђено је да ова четири фактора дају статистички поуздано решење и доказано је
} 
да су фактори позитивно повезани. Осим тога, резултати истраживања показали су да се мотивација студената за учење енглеског језика више подстиче читањем, учењем и ћаскањем него креирањем и израдом садржаја дигиталних и друштвених медија. Код студената је присутна интегрална мотивација за учење страног језика путем друштвених мрежа и дигиталних медија.

Кључне речи: друштвене мреже, дигитални медији, студенти инжењерства, интегрална мотивација, енглески језик.

\section{INTRODUCTION}

In recent years social networks have become widespread among young people as well as adults. Different kinds of online communication along with collaborative practice and participation through new generation gadgets and online games feature social networks communication as a widespread practice. Everyday face-to-face interaction is indispensably giving way to entertaining and meeting people at social networks as well as various kinds of media engagement for socializing (Galoyan and Madyarov, 2016; Ito and Bittanti, 2008). Thus, it could be expected that social networks have an important role in the development of young people's knowledge, everyday habits and identity. In addition, it sheds light on the issue how young people reflect on and assimilate cultural changes and novelties as well as extend their education. It is obvious that activities on social networks along with computer games, surfing on Internet, emailing and texting on mobile phones encourage cognitive and critical thinking (Shore, 2014), and that this pattern of behaviour has become an integral part of their lives. Some research works are dealing with the impact of social media on young people's attitudes and behaviour (Chau, 2010; Davidson \& Goldberg, 2009; Ekanayak \& Wishart, 2015; Galoyan and Madyarov, 2016; Ito and Bittanti, 2008; Kwok-Wong Lai \& Kian-Sam Hong, 2015; Palfrey et al., 2009; Prasek et al. 2009). The research of Rideout and associates (2010) found that students use digital technologies to a large degree when they are out of classes. Their mobile phones and laptops are used for messaging, speaking with their friends, listening to favourite music, and playing different games. The study reported three dominant online activities of young people: watching videos, playing games and exploring websites (Lai et al., 2013). It is apparent that this pattern of behaviour indispensably influence their mutual communication, socialization, learning activities and everyday habits. Several scholars (Oblinger \& Oblinger, 2005; Palfrey et al. 2009; Prensky 2001a, 2009; Rosen et al. 2010; Tapscott 2008) think that there is a difference in learning between present and prior generation of young people. The previous generations of young people had different levels of technology, motivation, concerns and media knowledge at different times, but today three different levels of engagement in media activities are investigated (Galoyan \& 
Mayarov, 2016; Ito et al., 2010). These activities are related to cultural, social and practical behaviour which is worldwide popular (Ahonen \& Kinnunen, 2015).

\section{Driving-force for Language Learning and Media}

Driving-force for language learning is undoubtedly vital in student's everyday learning activity. Insufficient motivation may cause serious problems in student's achievements even for gifted. The most important research in the field of motivation for learning foreign languages was conducted by Gardner and Lambert (1972). They regarded motivation as integrative and instrumental. Integrative motivation is based on students' need to identify with a culture whose language they learn. A true integrative motivation combines this need with the effort invested to achieve this goal, the desire to learn the language and favourable reactions to the language in the setting and context in which the language is spoken. Without these factors, integrative orientation is a goal that lacks motivation. It may happen that a person is interactively oriented, but not very motivated to learn a foreign language. On a series of research conducted on this topic it may be concluded that students with pronounced integrative motivation show a higher level of motivation intensity (Dörnyei and Ushioda., 2011).

On the contrary, instrumental motivation shows utilitarian orientation. It refers to student's desire to learn a language in order to achieve a goal like gaining a job, improving personal culture, or career advancement. The language is learned exclusively for pragmatic reasons without social or emotional context. Instrumental motivation can be very intense and often stronger than integrative motivation, but in relation to the integrative, in the long run, instrumental motivation has a tendency to last shorter (De Marco, 2000). On the other hand, Gardner defines the integrative motivation as more dominant because integratively oriented student has positive attitude towards language. However, learning a foreign language does not necessarily have to be purely instrumental or integrative. A person can also be integratively and at the same time instrumentally motivated because one type of motivation does not exclude the other. The crucial driving force does not have to be instrumental or integrative motivation, but motivation which develops dynamically during the learning process.

Probably the majority of people in our country learn foreign language at school, as part of the curriculum. When they start learning a foreign language, most students are motivated by the idea that in several months they will be able to communicate in that language. Mostly they are not aware of the demands and tasks which they will have to do in the process. Very often they are quite excited by the idea that they will learn another language and approach it with enthusiasm. This feeling, unfortunately, most often lasts short. The most frequent observations of foreign language teachers are that enthusiasm disappears before the end of the first year of learning. Out of the 
classroom, the conclusion remains the same. The difficulties faced by the students are born due to the fact that foreign language learning does not have much in common with other school subjects although students are often unaware of it. While learning a second language, there is a set of requirements and responsibilities that they should fulfil in order to pass the exam. Students are required to master linguistic contents (vocabulary, grammar), then they should acquire linguistic skills, develop a relationship towards the language they learn and finally they develop a desire to use the language outside the classroom.

An important motive for language learning is the attitude towards a country whose language is learned. While learning a foreign language students are inevitably encountered with the culture of the country where that language is spoken. Getting to know the new culture, i.e. customs, history, and mentality leads to the recognition and respect of the cultural and civilization values of the country where the target language is spoken. When the process of language learning encompasses both culture and civilization of target language, it leads to a comparative analysis at the level of cultural models of two countries, i.e. their own culture and culture of the target language. Therefore, it may be concluded that learning a new language contributes to the formation of a standpoint in which we evaluate every culture equally, we develop tolerance, destroy prejudices and stereotypes. Cultural competence is a necessary condition for socialization because the student who does not know or does not respect the cultural models of the country whose language he learns, he is considered uneducated when attempting to contact foreigners.

The role of digital media in language learning substantially questions the importance of formal education, and emphasizes the importance of informal learning (Mesić and Topolovčan, 2016). Development of knowledge, skills and abilities is no longer restricted on school education but students can seek for alternative ways of education at home. Internet provides flexible and open language learning for children, young people, as well as adults, or lifelong learning. The role of digital media provides a number of didactically valuable opportunities. It is primarily about the individualization of work, informal, flexible and open learning. Digital media enables development of critical and divergent thinking, self-determination and selfactualization, which are some of the elements of successful approach to adult language learning (Mezirow, 1997). In addition, it can significantly increase student's motivation and development of language skills through intercultural communication. Digital media enables direct contact with native speakers as well. Authentic communication significantly influences language acquisition and development of communication skills in informal situation. In addition, that is an opportunity to hear and learn different language varieties. In communication with native speakers, students learn fact knowledge about the culture and civilization of a particular country, as well as the values of the 
society whose language they are learning. It enables and encourages the development of tolerance between cultures, which is also one of the goals in language learning. Thus, digital media provide numerous opportunities in learning foreign languages.

Apart from intercultural competence, it is necessary to develop media competence as well when learning with digital media. It not only facilitates access to information sources, but also allows better understanding, analysis and assessment of content in foreign language (Velički, 2006). As we have already stated, the use of digital media enables and supports learning independently research and individualization of work, and non-school learning.

\section{Three Different Levels of Students' Engagement with Social Networks and Media}

Basic level of engagement. At this level of engagement Internet and mobile phones are very popular among young people, and online communication is regarded as acceptable, steady and preferred grounds of socialization (Galoyan \& Mayarov, 2016; Ito et al., 2010). Online conversation with friends and acquaintances through social networks and digital media has become common and widespread practice although in many cases face-to-face conversation exists and it is still a preferred way of communication. There are various ways of maintaining online communication with friends through social networks and digital media, such as mobile phone conversations and messaging, as well as browsing social network profiles. It is a distinctive online collaboration, but it also has much in common with the way of offline socializing and having fun with peers. Frequently, virtual co-existence with peers is established through checking friends' status updates on Twitter or Facebook or texting on mobile phones and in many ways it replaces physical companionship (Ito and Okabe, 2005).

Very often teens and young people use network communication to arrange meetings and socializing live. Network sites and communication devices have become a complementary site of the first level of engagement with social networks. In addition, they are also very fond of listening to music which is another way of entertaining and socializing with friends and peers. The habit of sharing, storing and listening to music is omnipresent nowadays, and music files are exchanged over the Internet as well. Information and images of favourite musicians, singers, bands or song lyrics are accompanying clips and links to videos and songs. Social site profiles are common places for displaying musical tastes and favourites.

Another common practice is a regular visit to YouTube, since videos and TV programs on this social network are highly appreciated. There is a fast increase of watching TV-shows on YouTube, although a lot of young people still watch TV shows on their TV sets. YouTube videos are placed within a suitable context by YouTube participants who often express their 
opinion and make comments which makes it socially interactive and enable young people to develop critical social skills. In addition, sharing and watching videos along with online communication are regarded as private space where young people are practicing freedom and independence.

Intermediate level of engagement. At this level of engagement Internet is regarded as the place for investigating young people's leisure activities and pursuits (Galoyan \& Mayarov, 2016; Ito et al., 2010). They are aware of media and its advantages since they have obtained information they were searching, so in time they develop the desire and ability to find general knowledge and play around with media. Consequently, information has become available and accessible easily which started changing young people's opinion (Eagleton \& Dobler, 2007; Hargittai, 2004; Robinson, 2007; Zillien \& Hargittai, 2009) and gaining reputation among their friends. Much online research involves collecting facts and data about a specific subject that later helps writing assignments and tasks as well as searching for a the solution of the problem. This is an important level of commitment when young people practice creative thinking and how media tool works while finding a solution for the problem, i.e. change images by digital photo tools. Playing computer games involves trial and error activities while experimenting on the key answer. Many important features of playing internet games are implicitly presented by authors, so young people learn about them from peers directly or indirectly from available sources.

This level of engagement also involves manipulating pictures and images by using different programs as well as shooting videos. It is a great opportunity to become famous among friends, classmates or family members if master advanced technology and become successful in technology skills. This type of participation is guided by young people's leisure activities eagerness to learn.

It was noticed that this level of engagement starts when entering college or faculty (Ito \& Bittanti, 2008). College students highly engaged in playing games, creative production or data manipulation meet each other at faculty and collaboratively continue developing their skills and enthusiasm. This kind of engagement with social networks and digital media shows the rewards of living in the time of interactive media.

Advanced level of engagement. This final level of commitment to social networks and digital media refers to a powerful engagement with communication technology. It deals with the everyday practice of some young people which is characterized by deep and specific knowledge of computer technology, repeated and exhaustive use of media and eagerness to disregard or violate technological and social rules (Galoyan \& Mayarov, 2016; Ito et al., 2010). Therefore, competence to engage with technology and media in an independent, powerful and beneficial way is regarded as exclusive quality of media setting nowadays. Great amount of information related to specific interests of young people is available on Internet, 
particularly for people possessing Internet access and new technology in their homes.

Changing the established practice refers to the second and third level of digital and social media engagement, but they are done differently. The second level is characterized by unclear conscientiousness of necessity and capability to challenge social conventions set by institutions such as faculty or school, or parents. The third level often involves imposing restrictions on access to information to establish recurrent and powerful interaction with technology and media. Changing and reshaping the rules on this level of engagement also includes eagerness to test technological limitations. This habit is mostly present when acquiring media which are inaccessible at local market or media that are unobtainable due to their cost. This level of engagement frequently includes complete disregard for current technical limitations as well as social and legal norms. Young people with passionate interests are pioneering in ways that revise and modify contemporary rules of media engagement.

There is an obvious and close link between students' engagement with social networks and digital media and their motivation to learn English when online communication depends on the need to use English as a communicative tool. Also, surfing the Internet for different reasons very often demands a good command of English. Therefore, further research is needed to examine the effects of social networks and digital media engagement of a specific group of users such as university students learning English as a foreign language. The target population in this study is from Serbia, a country where English is a foreign language. Much of nowadays social networks and digital media are English-medium so it opens up doors to many professional and personal development opportunities. Thus, the gap that we want to address in the current literature is relationship between university students' interest and engagement in social networks and digital media and their motivation to learn English. The aim of the research is to prove the existence of three types of engagement with social networks and digital media and to explore correlation between all three levels of engagement and motivation to learn English. Also, the type of motivation, i.e. integrative and instrumental will be investigated.

Thus, this research sets out to investigate three issues:

- Identifying whether the three types of engagement on social networks and digital media form their unique dimensions according to statistical analysis, such as factor analysis

- The relationship between students' engagement on social networks and digital media and their motivation to learn English

- The type of motivation to learn English when engaged with social networks and digital media

- Therefore three hypotheses are stated: 
H1: There are three types of students' engagement with social networks and digital media.

H2: Students are motivated to learn English at all three levels of engagement with social networks and digital media.

H3: Students' engagement with social networks and digital media is motivated by integrative motivation.

This study explores this relationship empirically using the following methodology.

\section{METHODOLOGY}

\section{Measures and Questionnaire Development}

The questionnaire was developed in accordance with previous studies and literature recommendations. Thus, only measures considering theoretical background and empirical validation were used. Face validity was checked by a group of university professors and students before a preliminary testing. Due to their suggestions some minor corrections were made. The preliminary testing was carried out with fifteen students from different departments. Students were asked to assess the questionnaire which was modelled after the one used in the previous research (Galoyan and Madyarov, 2016) and modified according to our research sample. Generally, there were not any major complaints about the length or clarity of the questionnaire. Finally, the questionnaire (Appendix 1) contained 30 items grouped into 3 dimensions of social networks and digital media engagement, and one dimension of motivation to learn English (Rutkowski \& Rutkowski, 2010). The respondents' subjective estimates were acquired using a five-point Likert scale (Nunnally and Bernstein, 1994).

The questionnaire was circulated to the students during the lectures and they all fill out the survey .

\section{Participants and Sampling}

A total of 353 students from the XXXXX, have participated in this research (Table 1). Their age ranged from 19-27. Since it is a convenience sample, students were divided into groups, based on the University departments. Thus, the sample is composed of randomly chosen participants from the departments of electrical and mechanical engineering, industrial management and biomedical engineering. Overall, the distribution of the participants by age, and study program are relatively equal, but there is an overrepresentation of males, which is due to the structure of students at technical faculties. This is shown in Table 1. 
Table 1. Number of participants by gender, age and study program

\begin{tabular}{lccrc}
\hline Department & Male & Female & Total & Age \\
\hline Electrical engineering & 64 & 28 & 92 & $19-27$ \\
Mechanical engineering & 47 & 14 & 61 & $20-22$ \\
Industrial management & 42 & 60 & 102 & $19-22$ \\
Bio-medical engineering & 52 & 46 & 98 & $19-20$ \\
\hline Total & 205 & 148 & 353 & - \\
\hline
\end{tabular}

\section{Data Analysis}

The data collected from the questionnaire were analyzed by using SPSS V.20. After the exploratory factor analysis -EFA, the questionnaire was tested for reliability measures and Spearman's correlations were used further to assess relationships between research dimensions.

Exploratory factor analysis - EFA. Social networks and digital media engagement and motivation to learn English were empirically validated and confirmed in a previous study (Galoyan and Madyarov, 2016); the empirical confirmation in the case of Serbia has been proved as well. Furthermore, the conditions in which the prior researches were carried out could vary between the respondents (Oliveri \& Ercikan, 2011). In addition, the structure of the study concept could be influenced by these differences. Thus, exploratory factor analysis (EFA) was carried out in order to explore and identify the structure of underlying factors (Asparouhov \& Muthén, 2014).

For the purpose of EFA, maximum likelihood extraction method was used. First, an unrotated factor solution was examined. The extraction results with eigenvalues greater than one (Thompson, 2004) have shown that the solution with four factors is adequate. Scree plot values also have yielded a four-factor solution (Figure 1). Eigenvalues and the percent of the explained variances for these factors ranged from 8.097 (35.203\%) to $1.562(6.791 \%)$. Cumulatively, four-factors solution explained $67.105 \%$ of the sample variance, which is acceptable (Thompson, 2004).

After that, the rotated factor solution, with the fixed number of factors (4) was applied. The promax method of rotation was used since it is expected that factors are correlated (Thompson, 2004).

Among 30 items, seven items cross-loaded on more than one factor or had a very low factor loading scores, below 0.4 (items 15.20, 16.1, 16.2, 16.3, $16.4,16.5$ and 16.10).

Thus, these items were omitted from the matrix structure (Thompson, 2004). Pattern matrix of the four-factor solution is shown in Table 2. List of all items is given in Appendix 2. Excluded items are marked with an asterisk $(*)$. 


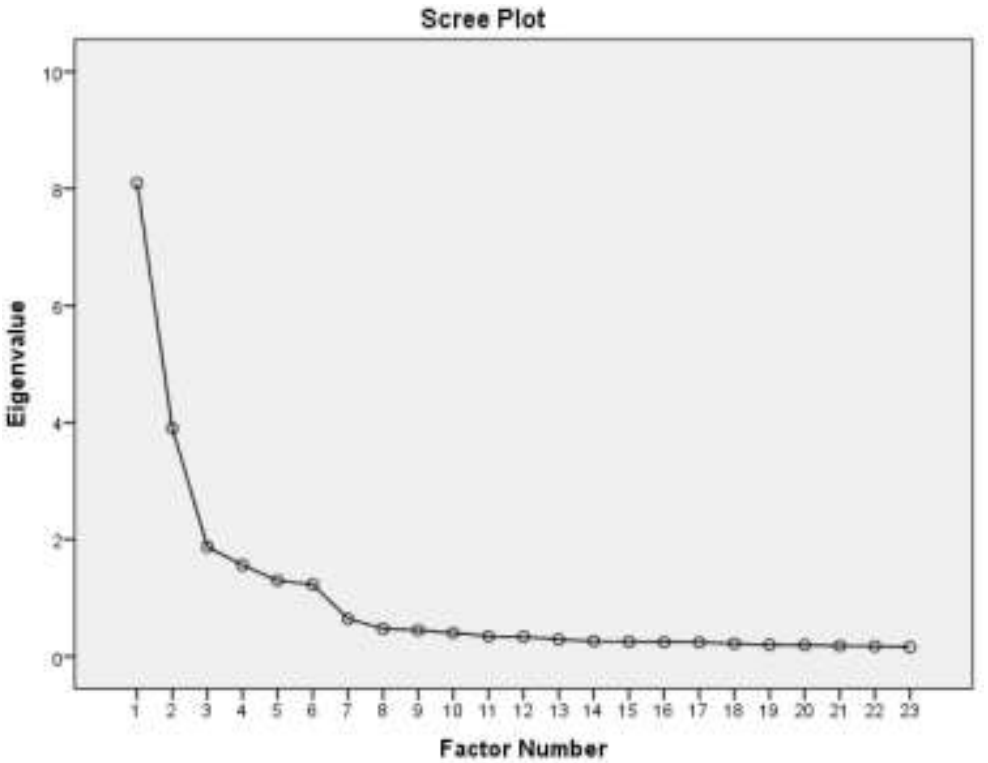

Figure 1. Factor scree plot

Table 2. Pattern matrix of the four-factor solution

\begin{tabular}{|c|c|c|c|c|}
\hline & 1 & 2 & 3 & 4 \\
\hline 15.16 & .921 & & & \\
\hline 15.18 & .917 & & & \\
\hline 15.17 & .861 & & & \\
\hline 15.15 & .827 & & & \\
\hline 15.19 & .767 & & & \\
\hline 15.6 & & .912 & & \\
\hline 15.5 & & .862 & & \\
\hline 15.4 & & .857 & & \\
\hline 15.7 & & .747 & & \\
\hline 15.3 & & .515 & & \\
\hline 15.1 & & .500 & & \\
\hline 15.2 & & .457 & & \\
\hline 15.9 & & & .855 & \\
\hline 15.11 & & & .837 & \\
\hline 15.10 & & & .792 & \\
\hline 15.8 & & & .604 & \\
\hline 15.13 & & & . 473 & \\
\hline 15.12 & & & .457 & \\
\hline 15.14 & & & .406 & \\
\hline 16.8 & & & & .878 \\
\hline 16.7 & & & & .845 \\
\hline 16.9 & & & & .797 \\
\hline 16.6 & & & & .469 \\
\hline
\end{tabular}


The remaining items formed three constructs of social networks and digital media engagement and one construct of motivation to learn English. With respect to the loading items, the first factor of the social networks and digital media engagement is recognized as "advanced level of engagement", followed by the second and third factor, respectively, "basic level of engagement" and "intermediate level of engagement". This solution is further analyzed by the Cronbah's alpha test of reliability, while the associations between these constructs were tested by the Spearman's correlations (Hair et al., 2009).

Reliability measures and Spearman Correlation Analysis. The reliability was conducted by calculating Cronbach $\alpha$ coefficient $(\alpha \geq 0.7$, Nunnaly and Berstein, 1994), for each construct of the EFA solution. All construct met this criterion (Table 2). The next step was to examine the correlation between the types of engagement with social networks and digital media and motivation to learn English. As seen from the table 3, correlations are moderate, however, statistically significant, which speak in favour of the empirical validation of these constructs in the context of the research population. Namely, this supports the idea that the dimensions of social networks constitute different constructs. Also, all three constructs of social networks engagement are positively associated with the motivation to learn English.

Table 3.Cronbah's $\alpha$ and Spearman (r) correlations among research constructs

\begin{tabular}{lcccccc}
\hline \multicolumn{1}{c}{ Construct } & Items & $\alpha$ & 1 & 2 & 3 & 4 \\
\hline 1. Advanced level of engagement & 5 & 0.933 & 1 & & & \\
2. Basic level of engagement & 7 & 0.892 & $0.190^{*}$ & 1 & & \\
3. Intermediate level of engagement & 7 & 0.863 & $0.557^{*}$ & $0.475^{*}$ & 1 & \\
4. Motivation to learn English & 4 & 0.849 & $0.228^{*}$ & $0.576^{*}$ & $0.389^{*}$ & 1 \\
\hline
\end{tabular}

*significant at the level 0.01 level (2-tailed).

According to table 2, it can be concluded that there is a distinction between the advanced and basic level of engagement with social networks and digital media. However, moving towards the higher levels of engagement, this distinction slowly fades away. Finally, the correlation between the basic level of engagement and motivation to learn English is the strongest. Thus, we can conclude that students' motivation to learn English is more fostered with their need to read, learn and chat, than to craft, produce and develop on social networks and digital media content.

Descriptive statistics of items, within aforementioned constructs, reveals that, in the case of Advanced level of engagement, item 15.15 is considered to be a predominant category, while for Basic and Intermediate Level, predominance is evident for items 15.5 and 15.8, respectively. Last but not the least, Motivation to learn English, is mostly influenced by the respondent desire and need to watch movies and video contents (i.e. item 16.7). This is shown in table 4. 
Table 4. Descriptive statistics of items, within research constructs.

\begin{tabular}{cccc}
\hline No. Construct & Item & Mean & StDev \\
\hline 1. Advanced level of engagement & 15.15 & 3.01 & 1.14 \\
& 15.19 & 2.97 & 1.10 \\
& 15.16 & 2.91 & 1.16 \\
& 15.17 & 2.89 & 1.20 \\
& 15.18 & 2.86 & 1.19 \\
\hline 2. Basic level of engagement & 15.5 & 3.30 & 1.12 \\
& 15.3 & 3.29 & 1.12 \\
& 15.1 & 3.27 & 1.14 \\
& 15.4 & 3.24 & 1.08 \\
& 15.6 & 3.23 & 1.12 \\
& 15.2 & 3.21 & 1.09 \\
& 15.7 & 3.09 & 1.07 \\
\hline Intermediate level of engagement & 15.8 & 3.14 & 1.08 \\
& 15.9 & 3.07 & 1.10 \\
& 15.11 & 2.97 & 1.08 \\
& 15.13 & 2.96 & 1.09 \\
& 15.10 & 2.96 & 1.17 \\
& 15.14 & 2.95 & 1.13 \\
& 15.12 & 2.94 & 1.07 \\
\hline 4. Motivation to learn English & 16.7 & 3.23 & 1.09 \\
& 16.8 & 3.18 & 1.11 \\
& 16.9 & 3.16 & 1.07 \\
& 16.6 & 2.93 & 1.13 \\
\hline
\end{tabular}

Values are given with respect to descending order of values for Mean, per construct.

The results show the following:

H1: There are three types of students' engagement with social networks and digital media is confirmed.

H2: Students are motivated to learn English at all three levels of engagement with social networks and digital media is confirmed.

H3: Students' engagement with social networks and digital media is motivated by integrative motivation is confirmed.

\section{RESULTS AND DISCUSSION}

An exploratory factor analysis has yielded three distinct factors of digital media engagement and one factor of motivation to learn English. The first one is the advanced level of engagement, followed by the basic level of engagement and intermediate level of engagement, respectively. This fourfactor solution was found to be statistically reliable. Also, it has been shown that factors are positively associated. Namely, three factors of digital media engagement form a statistically positive relationship between themselves, as well with the motivation to learn English. Thus, the results are interpretable 
in accordance with literature recommendations and they show similarities with previous research findings in the field.

It should be noted that this research is the only one in this country and south-eastern part of Europe, which provided empirical confirmation of the existence of the mentioned factors, i.e. levels of engagement with social networks and digital media and their correlation with motivation for learning English. The conditions in which the previous studies were carried out vary between the populations (Ito et al., 2010; Galoyan and Madyarov, 2016).

The goal of the project presented in Ito and associates (2010) was to provide evidence of everyday activities and interests of young people as they engage with new media and present a model for considering, learning, and taking part in current networked community. When describing new media engagements, several conditions were considered, i.e. social, technical, cultural, and all of them were required for certain forms of involvement. It was found that easy access to digital tools and Internet were prerequisites for successful participation on all social networks while investigating the kind of informal, peer-based communication which was popular among American teenagers. Unfortunately, the project lacks any empirical research on the stated results.

The paper (Galoyan and Madyarov, 2016) discussed the relationship between high school pupils' and their engagement with social networks and digital media and their motivation to learn English. Three types of engagement with social networks and digital media (hanging out, messing around and geeking out) made a conceptual framework. The study included questionnaire data collected from secondary school students in Armenia. Based on the correlation analysis it was found that the more intensively secondary school students geek out with social networks and digital media, the more likely they are motivated to learn English. The messing around and hanging out behaviour did not show a convincing relationship with students desire to learn English.

This research deals with university students and it shows that there is a distinction between the advanced and basic level of engagement with social networks and digital media. However, moving towards the higher levels of engagement, this distinction slowly fades away. Finally, the correlation between the basic level of engagement and motivation to learn English is the strongest. Thus, it can be concluded that students' motivation to learn English is more fostered with their need to read, learn and chat, than to craft, produce and develop digital and social media content. However, it should be pointed out that students who mainly read, learn and chat have less knowledge of English so their motivation is higher in comparison with those who craft, produce and develop digital and social media content since it is mostly done in English, so they already have a good command of it.

Exploratory factor analysis (EFA) was carried out in order to explore and identify the structure of underlying factors. Correlations between these 
factors are moderate, however, statistically significant, which speak in favour of the empirical validation of these constructs in the context of the research population. Namely, this supports the idea that the dimensions of social networks and digital media constitute different constructs. Also, all three constructs of social and digital media engagement are positively associated with the motivation to learn English. In the case of Advanced level of engagement creating graphics and animations, for example, Photoshop, Flash (i.e. item 15.15) is considered to be a predominant commitment and interest among the students. On the Basic level of engagement it is downloading and listening to music (i.e. item 15.5) while on Intermediate level of engagement it is using video instructions to learn something (i.e. item 15.8).

Finally, Motivation to learn English, is mostly influenced by the respondents' desire and need to watch movies and video contents (i.e. item 16.7) and it is the integrative motivation. In addition, students are motivated to learn English to enrol online English courses, listen to the lyrics in English online, and read online in English for fun. They show desire to learn the language in the setting and context in which the language is spoken.

\section{CONCLUSION}

Nowadays young people create, collaborate and share information through social networks and digital media (Mislter-Jackson \& Songer 2000; Dickey 2007; Heafner 2004; Prensky 2001b). Various discussion forums, blogs, micro blogs, wikis, live chat, podcasts, social networking sites provide them an opportunity to connect with each other and develop new alternative identities and modes of self-representation. At the same time, they become more motivated to study and use the English language as most of the web content is dominated by this language (Crystal 2003; Ranta 2010; Jenkins et al. 2009; Ushioda 2011).

There is an obvious lack of scholars' attention when dealing with carefully validating instruments that enable gathering data about university students' engagement in social networks and digital media. Serbian version of the questionnaire applied on a large sample of XXX university students in the study was validated using exploratory factor analysis. Analyses confirmed the existence of the three types of engagement with social networks and digital media. The results suggested that the Serbian version of the questionnaire is a valid instrument for research into XXX university students' engagement with social and digital media. The limitations of this research include using convenience sample and overrepresentation of males, which is due to the structure of students at technical faculties. This requires caution when it comes to the generalisation of the results.

In addition, this study showed that social networks and digital media stand in the relationship with a driving force to learn English as a foreign language. Since both intrinsic and extrinsic motivation is multidimensional 
phenomena they are influenced by many factors. Thus, future research may investigate the factors that influence motivation.

Also, some future research may consider different youth practices trying to understand and nurture their engagement in new media practices from their standpoint. Thus, the relationship between young people's activities and wider cultural and social structures and could be investigated in ways that consider the ever-changing particular nature of students' engagement with certain practices. Participation on social networks is a special learning and entertainment opportunity for young people that combines several motivational factors and offers new possibilities of learning and participation that evolve with changes in technology.

\section{REFERENCES}

Ahonen, A. K. and P. Kinnunen. 2015. How Do Students Value the Importance of Twenty First Century Skills? Scandinavian Journal of Educational Research, 59(4): 395-412.

Asparouhov, T., and O. Muthén. 2014. Multiple-group factor analysis alignment. Structural Equation Modeling: A Multidisciplinary Journal, 21(4): 495-508. https://doi.org/10.1080/10705511.2014.919210

Chau, C. 2010. YouTube as a participatory culture. New Directions for Youth Development, 12: 865-74. DOI: $10.1002 / y d .376$

Cristal, D. 2003. English as a Global Language. Cambridge: Cambridge University Press.

Davidson, C. and D. Goldberg, 2009. The future of Learning Institutions in a Digital Age. Cambridge, MA: The MIT Press.

De Marco, A. 2000. Manuale di glottodidattica. Carocci: Roma.

Dickey, M. D. 2007. Game Design and Learning: A Conjectural analysis of how massively multiple online role-playing games (MMORPGs) foster intrinsic motivation. Educational Technology Research and Development, 55(3): 253-273.

Dornyei, Z., and E. Ushioda. 2011. Teaching and researching motivation (2nd ed.). Flarlow, UK: Longman.

Eagleton, M.B. and E. Dobler. 2007. Reading the Web: Strategies for Internet Inquiry. New York: Guilford Press.

Ekanayake, S.Y. and J. Wishart. 2015.Integrating mobile phones into teaching and learning: A case study of teacher training through professional development workshops, British Journal of Educational Technology, 46(1): 173-189.

Galoyan, T., and Madyarov, I. 2016. The relationship between the types of engagement with digital and social media and motivation to learn English. In Mirici, I.H. et al. (Eds.) Research Papers on Teaching English as an Additional language. (pp.103124) University of Rijeka: Rijeka.

Gardner, R. C., and Lambert, W. E. 1972. Attitudes and motivation in second language learning. Rowley, MA: Newbury House.

Hair, J.F., Black, W.C., Babin, B.J., and R.E. Anderson. 2009. Multivariate Data Analysis (7th ed.), Prentice Hall, US.

Hargittai, E. 2004. Do You "Google"? Understanding Search Engine Popularity Beyond the Hype. First Monday. 9(3) Retrieved from: http://firstmonday. org/issues/ issue9_3/hargittai/index.html).

Heafner, T. 2004. Using technology to motivate students to learn social studies. Contemporary Issues in Technology and Teacher Education, 4(1): 42-53. 
Ito, M. and D. Okabe. 2005. Technosocial Situations: Emergent Structuring of Mobile Email Use. in Ito, M., Okabe, D., and M.Matsuda. (Eds) Personal, Portable, Pedestrian: Mobile Phones in Japanese Life. (pp. 257-73). Cambridge, MA: The MIT Press.

Ito, M. and M. Bittanti. 2008. Kids' informal learning with digital media: An ethnographic investigation of innovative knowledge cultures: Final report: Gaming digital youth research. Retrieved from: http://digitalyouth.ischool.berkley.edu/book-gaming.

Ito, M., Baumer, S., Bittanti, M., Boyd D., Cody R., Herr-Stephenson B., and L.Tripp. 2010. Hanging out, messing around and geeking out. Cambridge, MA: The MIT Press.

Jenkins, H., Clinton, K., Purushotma, R., Robison, A.J., \& Weigel, M. 2009. Confronting the Challenges of Particularly Culture: Media Education for the 21st century. Cambridge, MA: The MIT Press.

Kwok-Wing Lai and Kian-Sam Hong. 2015. Technology use and learning characteristics of students in higher education: Do generational differences exist?. British Journal of Educational Technology, 46(4): 725-738.

Lai, K.W., Khaddage, F. and G. Knezek. 2013. Blending student technology experiences in formal and informal learning, Journal of Computer Assisted Learning, Vol. 29 (5), 414-425.

Mesić, M. and Topolovčan, T. 2016. Cjeloživotno učenje učitelja u digitalnom dobu: uloga ciljnih orijentacija u poslu i društvenih mreža. [Teacher's lifelong learning in the digital age: The role of a workdomain goal orientations and social networks] Andragoški glasnik, 20(1-2), 59-82.

Mezirow, J. (1997). Transformative learning: Theory to practice. New Directions for Adult and Continuing Education, 74, 5-12.

Mislter-Jackson, M., and N. B. Songer. 2000. Student Motivation and Internet Technology: Are Students Empowered to Learn Science? Journal of Research in Science Teaching. 37(5): 459-479.

Nunnaly, J., and H. Bernstein. 1994. Psychometric theory. New York: McGraw-Hill Inc.

Oblinger, D. and J. Oblinger. 2005. Educating the Net Generation, Educause. Retrieved from: www.educause.edu/educatingthenetgen/

Oliveri, M. E., and K. Ercikan. 2011. Do different approaches to examining construct comparability in Multilanguage assessments lead to similar conclusions? Applied Measurement in Education, 24(4): 349-366. https://doi.org/10.1080/08957347. 2011.607063

Palfrey, J., Gasser, U., Simun, M., and R. F. Barnes. 2009. Youth Creativity \& Copyright in Digital Age. International Journal of Learning and Media, 1(2): 79-97.

Prasek, M. Schwartz, A. and K.V. Vorst. 2009. Technology Integration: Effects on Motivation, Engagement \& Interests. Final Project: LT785 - Research Methods in Educational Technology. Retrieved from: http://kv023.k12.sd.us/LT785/Final\% 20project.pdf

Prensky, M. 2001a. Digital natives, digital immigrants, part 1. On the Horizon, 9(5): 1-6.

Prensky, M. 2001b. Digital natives, digital immigrants, part 2: Do they really think differently? On the Horizon, 9(6): 1-6.

Prensky, M. 2009. H. sapiens digital: From digital immigrants and digital natives to digital wisdom. Journal of Online Education, 5(3): 1-9

Ranta, E. 2010. English in the Real World vs. English at School: Finish English Teachers and Students' Views. International Journal of Applied Linguistics, 20(2), 156-177.

Robinson, L. 2007. Information the Wiki Way: Cognitive Processes of Information Evaluation in Collaborative Online Venues. Proceedings of International Communication Association Conference, 124-132, San Francisco. CA. 
Rideout, V. J., Foehr, U. G., and D.F. Roberts. 2010.Generation M2: Media in the Lives of 8-18-Year-Olds.Menlo Park, CA: Henry J. Kaiser Family Foundation.

Rosen, J. A., Glennie, E. J., Dalton B. W., Lennon, J. M., and R.N.Bozick. 2010. Noncognitive Skills in the Classroom:New Perspectives on Educational Research. RTI Press.Retrieved from http://www.rti.org/rtipress.

Shore, R. 2014. Excellent teaching in an unexpected place. Kappa Delta Pi Record 50(4): $16-21$.

Tapscott, D. 2008. Grown Up Digital: How the Net Generation is Changing Your World, McGraw-Hill, 2008.

Thompson, B. 2004. Exploratory and confirmatory factor analysis: Understanding concepts and applications. American Psychological Association, Washington, DC.

Ushioda, E. 2011. Language learning motivation, self, and identity: Current theoretical perspectives. Computer Assisted Language Learning, 24(3): 199-210.

Velički, D. 2006. Medijska kompetencija i upotreba novih medija u nastavi stranih jezika. [Media competence and the use of new media in teaching foreign languages] $\mathrm{U}$ Granić, J. (Ur.), Jezik i mediji - jedan jezik: više svjetova. Zagreb - Split: HDPL, 723-732.

Zillien, N. and E. Hargittai. 2009. Digital Distinction: Status-Specific Types of Internet Usage. Social Science Quarterly, 90(2): 274-291.

\section{Appendix 1 \\ Questionnaire on Social Networks and Students' Motivation to Learn English}

\begin{tabular}{|c|c|c|}
\hline \multicolumn{2}{|c|}{ Question } & Code \\
\hline \multicolumn{2}{|c|}{$R . \_n u m b e r$} & R._number of \\
\hline \multicolumn{2}{|c|}{ of participants } & participants \\
\hline \multicolumn{2}{|c|}{ Department } & Department \\
\hline 1. & Gender & 1.Gender \\
\hline 2. & Age & 2.Age \\
\hline 3. & Faculty & 3.Faculty \\
\hline 4.1. & I have a personal computer & 4.1 \\
\hline 4.2 . & I have a laptop & 4.2 \\
\hline 4.3. & I have an iPad/Android tablet & 4.3 \\
\hline 4.4 . & I have a Smartphone & 4.4 \\
\hline 5. & Do you have an Internet access at home? & 5. \\
\hline 6. & Do you have an Internet access at Faculty? & 6. \\
\hline 7.1. & What language/languages do you learn at Faculty?English & 7.1 \\
\hline 7.2 . & What language/languages do you learn at Faculty?German & 7.2 \\
\hline 7.3. & What language/languages do you learn at Faculty? French & 7.3 \\
\hline 7.4. & What language/languages do you learn at Faculty?Russian & 7.4 \\
\hline 8. & What foreign language would you like to learn? & 8 \\
\hline 9.1 . & What are your hobbies/interests?Music & 9.1 \\
\hline 9.2. & What are your hobbies/interests? Film & 9.2 \\
\hline 9.3. & What are your hobbies/interests?Sport & 9.3 \\
\hline 9.4. & What are your hobbies/interests?IT & 9.4 \\
\hline 9.5. & What are your hobbies/interests?Drawing & 9.5 \\
\hline 9.6. & What are your hobbies/interests?Design & 9.6 \\
\hline 9.7. & What are your hobbies/interests?Reading & 9.7 \\
\hline 9.8 . & What are your hobbies/interests?Socializing & 9.8 \\
\hline & Does the Internet help you pursue your hobbies/interests? & 10. \\
\hline
\end{tabular}


11. Does English help you pursue your interests? 11.

12.1. How often do you use the following social sites? Facebook 12.1

12.2. How often do you use the following social sites? Instagram 12.2

12.3. How often do you use the following social sites? Youtube 12.3

12.4. How often do you use the following social sites? Twitter $\quad 12.4$

12.5. How often do you use the following social sites? Snapchat 12.5

12.6. How often do you use the following social sites? Google+ 12.6

12.7. How often do you use the following social sites? LinkedIn 12.7

13. Do you use English when communicating with your friends on social sites?

14.1. I need English for future job/career

14.2. I need English because my parents want me to 14.2

14.3. I need English to create something using a computer 14.3

14.4. I need English for my entrance exam 14.4

15.1. I exchange information with my friends through texting and online communication $\quad 15.1$

15.2. I use online groups or forums to learn something 15.2

15.3. I surf the Internet to find interesting information 15.3

15.4. I search and read professional literature on the Internet 15.4

15.5. I download and listen to music on the Internet $\quad 15.5$

15.6. I download and watch films or videos on the Internet 15.6

15.7. I make and edit video and audio software $\quad 15.7$

15.8. I use video tutorials to learn something 15.8

15.9. I play computer games 15.9

15.10. I make computer games $\quad 15.10$

$\begin{array}{ll}\text { 15.11. I buy online } & 15.11\end{array}$

15.12. I listen to Podcasts for pleasure $\quad 15.12$

15.13. I listen to Podcasts to learn something $\quad 15.13$

15.14. I create Podcasts $\quad 15.14$

15.15. I create graphics or animations, e.g. Photoshop, Flash 15.15

$\begin{array}{lr}\text { 15.16. I create websites } & 15.16\end{array}$

15.17. I have a blog $\quad 15.17$

15.18. I exchange information with friends through wikis 15.18

15.19. I do computer programming $\quad 15.19$

15.20. I attend online courses to learn something new $\quad 15.20$

16.1. I use English on social sites $\quad 16.1$

16.2. I use English for searching interesting information 16.2

16.3. I use English for socializing online 16.3

16.4. I self-study in English 16.4

16.5. I take offline English language tutorials in my free time 16.5

16.6. I take online English language tutorials in my free time $\quad 16.6$

16.7. I watch English movies and videos 16.7

16.8. I listen to English songs 16.8

16.9. I read for fun in English 16.9

16.10. I use English to program/create something 16.10 


\section{Appendix 2}

15.1. I exchange information with my friends through texting and online communication

15.2. I use online groups or forums to learn something

15.3. I surf the Internet to find interesting information

15.4. I search and read professional literature on the Internet

15.5. I download and listen to music on the Internet

15.6. I Iownload and watch films or videos on the Internet

15.7. I make and edit video and audio software

15.8. I I use video tutorials to learn something

15.9. I play computer games

15.10. I make computer games

15.11. I buy online

15.12. I listen to Podcasts for pleasure

15.13. I listen to Podcasts to learn something

15.14. I create Podcasts

15.15. I create graphics or animations, e.g. Photoshop, Flash

15.16. I create websites

15.17. I have a blog

15.18. I exchange information with friends through wikis

15.19. I do computer programming

*15.20. I attend online courses to learn something new

*16.1. I use English on social sites

*16.2. I use English for searching interesting information

*16.3. I use English for socializing online

*16.4. I self-study in English

*16.5. I take offline English language tutorials in my free time

16.6. I take online English language tutorials in my free time

16.7. I watch English movies and videos

16.8. I I listen to English songs

16.9. I read for fun in English

*16.10. I use English to program/create something

\section{ОДНОС ИЗМЕБУ ДРУШТВЕНИХ МРЕЖА \\ И ДИГИТАЛНИХ МЕДИЈА И МОТИВАЦИЈЕ СТУДЕНАТА ЗА УЧЕЊЕ ЕНГЛЕСКОГ ЈЕЗИКА}

Јелисавета Шафрањ, Јелена Зивлак, Ранко Бојанић

Универзитет у Новом Саду, Факултет техничких наука, Нови Сад, Србија

\section{Резиме}

Данас млади људи све чешће стварају, сарађују и деле информације путем друштвених мрежа и дигиталних медија који пружају бројне могућности за учење страног језика. Различити форуми за дискусије, блогови, микро блогови, викији, подкасти, веб странице за друштвено умрежавање пружају нове могућности да се млади повежу међусобом и развију нове алтернативне идентитете и начине самопредстављања. Такође, интернет пружа могућност за флексибилно и 
непосредно учење страног језика, како за младе, тако и за одрасле, као и могућност целоживотног учење. Улога дигиталних медија у учењу подразумева бројне дидактички вредне могућности, пре свега индивидуализацију учења, неформално, флексибилно и директно учење. Они стимулишу развој критичког и дивергентног мишљења и самоактуализацију што су неки од елемената успешног учењу страног језика одраслих. Поред тога, могу значајно повећати мотивацију и развој језичких вештина путем интеркултуралне комуникације јер омогућавају директан контакт са изворним говорником. Аутентична комуникација значајно утиче на усвајање језика и развијање комуникативних вештина у неформалној ситуацији. Поред тога, то је прилика да се чују и науче различите језичке варијанте. Такође, у комуникацији са изворним говорником усваја се чињенично знање о култури и цивилизацији одређене земље, као и вредностима друштва чији се језик уче. Дигитални медији омогућују и подстичу развој толеранције међу културама, што је уједно и један од циљева учења страног језика. С друге стране учешће на друштвеним мрежама је посебна прилика за учење и забаву која комбинује неколико мотивацијских фактора и нуди нове могућности учења као последица променама у технологији. Истовремено млади људи су више мотивисани да користе и уче енглески језик с обзиром да је већина веб садржаја на енглеском.

У овом раду се говори о односу између друштвених мрежа, дигиталних медија и мотивације студената за учење енглеског као страног језика. Истраживањем је обухваћено 353 студента техничких наука. Први део упитника односи се на укљученост студената у дигиталне медије, а други на њихову мотивацију за учење енглеског језика. Експлоративна факторска анализа издвојила је три фактора укључености у друштвене мреже и дигиталне медије, те један фактор мотивације за учење енглеског језика. Истраживање је омогућило емпиријску потврду постојања наведених фактора при чему је утврђено да ова четири фактора дају статистички поуздано решење и доказано је да су фактори позитивно повезани. Осим тога, резултати истраживања показују да се мотивација студената за учење енглеског језика више подстиче читањем, учењем и ћаскањем него креирањем и израдом садржаја дигиталних и друштвених медија. Код студената је присутна интегрална мотивација за учење страног језика путем друштвених мрежа и дигиталних медија. Добијени резултати указују да је српска верзија упитника валидан инструмент за истраживање ангажованости студената на друштвеним мрежама и дигиталним медијима. Ограничења овог истраживања укључују пригодан узорак у коме је више мушких испитаника у односу на женске, што је последица структуре студената на техничким факултетима. Ово захтева опрезност када је у питању уопштавање резултата.

Пошто су и инструментална и интегрална мотивација мултидимензионални феномени, што значи да на њих утиче више фактора, будућа истраживања би требало усмерити на проучавање тих фактора. Такође, могу се истражити и различите навике и ставови младих људи који покушавају да са свог становишта разумеју и процене ангажовање у новим медијима. Дакле, може се истражити однос између активности младих и шире културне и друштвене структуре када се узме у обзир променљива природа учешћа у дигиталним медијима. 